\title{
PUPILS' PERCEPTION OF COGNITIVE ADVANTAGES OF INTERNET USE WHILE TEACHING GEOGRAPHY IN PRIMARY AND SECONDARY SCHOOLS
}

\author{
Tamara S. Jovanović*, Aleksandra S. Dragin*, Anđelija Ivkov-Džigurski*, \\ Ljubica Ivanović Bibićc ${ }^{* 1}$ Branko Ristanović* \\ " University of Novi Sad, Faculty of Sciences, Departament of Geography, Tourism \\ and Hotel Management, Novi Sad
}

\begin{abstract}
This research aims to determine whether internet-assisted teaching is adequate for pupils and whether they perceive the Internet as useful for cognitive processing of curricula. Pupils' perceptions of cognitive advantages of Internet usage in teaching geography were examined. Specifically, we explored several aspects of cognition: memory, learning, mental schemas, computation and reasoning. We also considered the effects of pupils' gender, grade, type of school they attend and computer possession. Questionnaires were distributed to 1,563 pupils of different grades and types of primary and secondary schools in Serbia. There were two significant main effects - gender and grade and type of school. Furthermore, there were two significant interaction effects - computer possession with grade and type of school and gender with grade and type of school.
\end{abstract}

Keywords: cognitive advantages, geography teaching, internet, pupils' perception, Serbia.

\section{Introduction}

In the last two decades, many studies have been conducted on the relationship between learning and Internet usage among children and adolescents

1 Corresponding author: Lj. Ivanović Bibić, University of Novi Sad, Faculty of Sciences, Departament of Geography, Tourism and Hotel Management, Novi Sad;

e-mail: ljubicaivanovicns@yahoo.com 
(Dragin, Solarević and Ivkov-Džigurski, 2010; Durkin, Conti-Ramsden, Walker and Simkin, 2009; Greenfield and Yan, 2006; Gross, 2004; Johnson, 2006, 2008a, 2008b, 2010a, 2010b, 2010c; Joinson, 2003; Macia Arce, Rodriguez Lestegas and Armas Quinta, 2017; Stojanović et al., 2017; Subrahmanyam, Greenfiled, Kraut and Gross, 2001a; Subrahmanyam, Kraut, Greenfield and Gross, 2001b; Tarpley, 2001; Živković and Jovanović, 2006). In general, children who frequently use the Internet cognitively outperform infrequent Internet users. Internet usage mostly evokes and impacts verbal and visual cognitive abilities and findings also suggest that extensive and appropriate usage of the Internet increases human capacity to reason (Johnson, 2008b). Interestingly, if pupils use the Internet at home and at school, a teacher's evaluation of their cognitive development will be more positive (Johnson, 2008b). In order to access websites, a child must have developed metacognitive processes such as evaluation of information and planning as well as strategies for searching websites (Tarpley, 2001). Internet usage stimulates cognitive development - visual aspects of intelligence specifically - because computer usage requires perception of several visual stimuli at the same time - simultaneous reading of diagrams, recognizing icons and spatial relationships (DeBell and Chapman, 2006). Since research clearly shows that there is a significant positive impact of Internet usage on cognitive development, the question is are pupils aware of that benefit of Internet usage? What perception do children and adolescents have of the usefulness of Internet usage in classrooms for cognitive functioning? These questions are the base of this research.

Research shows that nowadays there are mostly no differences between boys and girls probably because they are all members of Net generation (born after 1977). Somewhat recent statistics show that females are as frequent Internet users as males (Carlsson and Facht, 2002), but they use it for different purposes males use the Internet more for video games, while females use it more for communication (Jackson et al,. 2007; Jupiter Communications, 2000; Subrahmanyam et al., 2001a).

It has become clear that the experience of learning has evolved into a mixed combination of traditional methods and learning methods based on technology (Singh and Reed, 2001), all to achieve maximal efficiency in the learning process (Clark, 2003). Aplication of modern media implies changes in teaching at all levels of education and facilities (Andjelković and Pavlović, 2015). Geography is one of the central subjects in the national educational system because the synthesis of the spatial complex of geosphere responds to the requirements of the 21st century (Leščešen, Dolinaj and Pantelić, 2017). Since the end of the past century, the Internet has been considered beneficial to the process of teaching geography in schools (Lemke and Ritter, 2000). Most of the developed countries have all the resources for computer-based teaching and it is up to geography lecturers to utilize this type of stimulating medium for teaching their students. Internet ma- 
terials help students to use time efficiently and enhance learning geography at schools and at home (Ritter and Lemke, 2000). One of the main tasks of teaching geography is that students acquire knowledge permanently in order to apply it in new teaching and life situations, and to minimize the process of forgetting in every manner possible (Milošević et al., 2016; Višnić et al., 2017). Some research shows that the educational process in schools in Serbia in most cases is still implemented in the traditional way, the student still has a passive role, and the teacher is the one who dominates the classroom and the student demands reproductive memorizing facts (Živković et al., 2017).

However, there is a lack of available researches on the perception of the benefits of Internet usage in teaching geography for cognitive functioning of children and adolescents, which was the goal of this research. There is only one research in Serbia about Internet usage while teaching geography (Dragin et al. 2010) and it served as the basis for this research. Dragin et al. (2010) conducted their research in 18 primary and secondary schools in Serbia, with the total sample of 788 pupils. The analyses show that pupils have mentioned geography as a favorite subject 112 times (15\% of pupils). Over $90 \%$ of primary and secondary school pupils own a home computer (in some schools this percentage is $100 \%$ ). Respondents have also stated that they started using computers at the age of three which is at least 4 years before acquiring general literacy (at schools). There were no significant differences in the frequency of Internet usage between primary and secondary school pupils - $80 \%$ use it on daily basis. In geography classes, less than $20 \%$ of pupils reported that their teachers used the Internet (13\% of primary school pupils and $17 \%$ of secondary school pupils). They mostly use the Internet at school to: visit Wikipedia, use Google translate, visit official school sites, to communicate (through Facebook and Skype), download images (illustrations, graphs, etc.) and texts for writing course papers and presentations.

These findings served as an inspiration for this paper, where we aimed to determine pupils' perception of the Internet usefulness for cognitive functioning in geography classes. We explored whether there are differences in that perception, depending on pupils' age, gender, grade, type of school they attend and computer possession. Specifically, we explored the Internet benefits for several aspects of cognitive processing: memory, learning, mental schemas, computation and reasoning. Since we know that most of children and adults in developed countries are already used to spending time on the computer and the Internet (Bevort and Breda, 2008; Lenhart, Madden and Hitlin, 2005; Roberts and Foehr, 2008), the authors also wanted to determine if that is the case in developing countries such as Serbia. 


\section{Methodology}

Participants of this study are 1,563 pupils of different grade and type of school in Serbia who use the Internet in geography classes. Pupils from upper elementary grades $\left(6^{\text {th }}, 7^{\text {th }}\right.$ and $\left.8^{\text {th }}\right)$ are chosen because of their cognitive maturity and experience with school's technological capabilities whereas the criteria for choosing pupils from secondary schools is whether they had geography or not in their curricula. In career schools (three-year and four-year job-specific training) geography courses are held in the first two years while in gymnasium schools (four-year secondary schools that prepare students for university education) they are held in the first three years. A little more than half are primary school pupils (55.7\%), $24 \%$ are career school pupils and $20.3 \%$ are gymnasium school pupils. Respondents' age ranges from 12 to 18 years and most of them $(49.5 \%)$ are either 14 or 15 years of age $\left(8^{\text {th }}\right.$ grade of primary school and $1^{\text {st }}$ grade of secondary schools). The percentages of male and female respondents are almost the same (male - $49.5 \%$, female - 50.4\%). Most of them have computers at home $(96.0 \%)$ and use it every day $(72.6 \%)$ or several times a week $(19.2 \%)$. The respondents have mostly used computers for more than a year $(91.3 \%)$ and almost all claim that they use the Internet at home (97.7\%).

For the purposes of this study a questionnaire was constructed. It consisted of 14 questions divided into two segments. In the first segment pupils were asked about their general characteristics: grade and type of school, gender, favorite subjects (max. three) and usage of computer at home (possession of a computer, frequency and purpose of its use). In the second segment respondents described their Internet usage: the purpose of its usage at home, Internet usage at school (technical capabilities, Internet application in subjects, frequency and purpose of its usage in geography classes) and cognitive advantages of Internet usage in geography classes. To determine cognitive advantages following statements were used:

- Information is longer retained in memory (memory);

- Connecting and interpreting information is easier (mental schema);

- It's quicker to find information online (computation and reasoning);

- It's easier to go on the Internet than to look for information in books (computation and reasoning);

- Using the Internet while teaching geography advances the process of learning this subject (learning).

The research was conducted in the period from 2011 to 2015 (four academic years). Geography students collected data as a part of course requirements. Pupils filled the questionnaires in person (typical pen and paper procedure) and were informed about the goal and anonymity of this research. Participation in this research was voluntary. 


\section{Results}

Data analyses were conducted using SPSS 17. Geography was mentioned as a favorite subject 339 times (21.7\%). This means that every fifth pupil emphasized geography as one of three top subjects (see Table 1).

Table 1. Frequency of choosing geography as one of three favorite subjects in school

\begin{tabular}{|l|r|r|}
\hline \multicolumn{1}{|c|}{ Geography } & frequency (f) & percent (\%) \\
\hline First place & 138 & 8,8 \\
\hline Second place & 125 & 8,0 \\
\hline Third place & 76 & 4,9 \\
\hline
\end{tabular}

As for the indicators of cognitive benefits of Internet usage while teaching geography (ITG), average answers are shown in the Table 2. Pupils perceived that ITG had the greatest benefit for the process of learning. It was estimated that ITG had the smallest benefit for retaining information (memory). Apart from learning, most of the benefits of ITG were perceived as rather small, i.e. below average.

Table 2. Average answers for the indicators of cognitive benefits of ITG

\begin{tabular}{|l|c|}
\hline \multicolumn{1}{|c|}{ Items } & Average answers \\
\hline Information is longer retained in memory (memory) & 2.42 \\
\hline Connecting and interpreting information is easier (mental schema) & 2.77 \\
\hline It's quicker to find information online (computation and reasoning) & 2.77 \\
\hline $\begin{array}{l}\text { It's easier to go on the Internet than look in a book for information } \\
\text { (computation and reasoning) }\end{array}$ & 2.67 \\
\hline $\begin{array}{l}\text { Using the Internet while teaching geography advances the process of } \\
\text { learning this subject (learning) }\end{array}$ & 4.04 \\
\hline
\end{tabular}

Even though pupils generally appraised cognitive benefits of the Internet lower than expected, we wanted to determine if there are any effects of gender, grade, type of school they attend and computer possession on the perception of these benefits. To this purpose we used general linear modeling (GLM). The results of this analysis are presented in Table 3 . It was found that gender differences play a significant role in forming mental schemas and processes of computation and reasoning. Individually, the variable of having computer at home does not influence the perception of any cognitive advantages of ITG. Grade and type of school significantly influence pupils' perception of ITG benefits for all cognitive processes except for learning. There are also significant interactions 
between computer possession, grade and type of school and interactions between gender, grade and type of school (see Table 3). None of the predictors has significant influence on the perception of ITG benefits for learning and almost all influence the perception of ITG benefits for forming mental schemas.

Table 3. Results of GLM

\begin{tabular}{|c|c|c|c|c|c|c|}
\hline Source & Dependent Variable & $\begin{array}{c}\text { Type III } \\
\text { Sum of Squares }\end{array}$ & df & $\begin{array}{l}\text { Mean } \\
\text { Square }\end{array}$ & $\mathbf{F}$ & Sig. \\
\hline \multirow{5}{*}{ Gender } & $\begin{array}{l}\text { 1. Information is longer } \\
\text { retained in memory }\end{array}$ & 2,734 & 1 & 2,734 & 1,618 & ,204 \\
\hline & $\begin{array}{l}\text { 2. Connecting and interpreting } \\
\text { information is easier }\end{array}$ & 11,529 & 1 & 11,529 & 6,210 &, 013 \\
\hline & $\begin{array}{l}\text { 3. It's quicker to find } \\
\text { information online }\end{array}$ & 17,291 & 1 & 17,291 & 9,047 & ,003 \\
\hline & $\begin{array}{l}\text { 4. It's easier to go on the } \\
\text { Internet than look in a book for } \\
\text { information }\end{array}$ & ,671 & 1 & 671 & ,321 &, 571 \\
\hline & $\begin{array}{l}\text { 5. Using the Internet while } \\
\text { teaching geography advances } \\
\text { the process of learning this } \\
\text { subject }\end{array}$ & 1,008 & 1 & 1,008 & 607 & ,436 \\
\hline \multirow{5}{*}{$\begin{array}{l}\text { Having a } \\
\text { computer at } \\
\text { home }\end{array}$} & 1 & 3,486 & 1 & 3,486 & 2,063 & ,152 \\
\hline & 2 & 1,106 & 1 & 1,106 &, 596 & ,440 \\
\hline & 3 & ,070 & 1 & 070 & ,036 & ,849 \\
\hline & 4 & 247 & 1 & ,247 & ,118 & 731 \\
\hline & 5 & ,217 & 1 & ,217 & 131 & ,718 \\
\hline \multirow{5}{*}{$\begin{array}{l}\text { Grade and } \\
\text { type of } \\
\text { school }\end{array}$} & 1 & 133,961 & 7 & 19,137 & 11,325 & , 000 \\
\hline & 2 & 163,096 & 7 & 23,299 & 12,551 &, 000 \\
\hline & 3 & 177,706 & 7 & 25,387 & 13,282 &, 000 \\
\hline & 4 & 171,243 & 7 & 24,463 & 11,713 &, 000 \\
\hline & 5 & 15,919 & 7 & 2,274 & 1,369 & ,216 \\
\hline \multirow{5}{*}{$\begin{array}{l}\text { Having a } \\
\text { computer } \\
\text { at home* } \\
\text { Grade and } \\
\text { type of } \\
\text { school }\end{array}$} & 1 & 4,465 & 3 & 1,488 & 881 & ,451 \\
\hline & 2 & 15,125 & 3 & 5,042 & 2,716 & ,044 \\
\hline & 3 & 13,815 & 3 & 4,605 & 2,409 &, 066 \\
\hline & 4 & 16,790 & 3 & 5,597 & 2,680 & ,046 \\
\hline & 5 & 9,881 & 3 & 3,294 & 1,983 & ,116 \\
\hline \multirow{5}{*}{$\begin{array}{l}\text { Gender* } \\
\text { Grade and } \\
\text { type of } \\
\text { school }\end{array}$} & 1 & 11,281 & 7 & 1,612 & ,954 & ,465 \\
\hline & 2 & 22,528 & 7 & 3,218 & 2,634 & ,049 \\
\hline & 3 & 15,633 & 7 & 2,233 & 1,168 & ,319 \\
\hline & 4 & 10,124 & 7 & 1,446 & 693, & 678 \\
\hline & 5 & 7,148 & 7 & 1,021 & 615, & ,744 \\
\hline
\end{tabular}



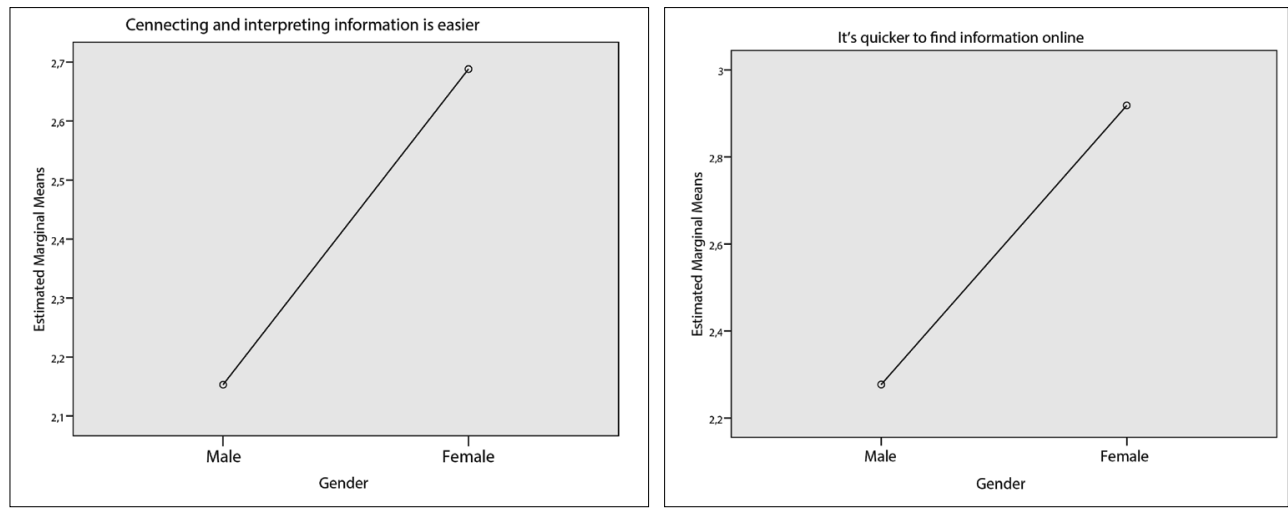

Figure 1-2. Gender differences in perception of cognitive benefits of ITG

Female pupils perceive more benefits of Internet usage in geography teaching for cognitive processing. Specifically, girls consider ITG useful for creating mental schemas and for computation and reasoning processes (see Table 3 and Figure 1-2).
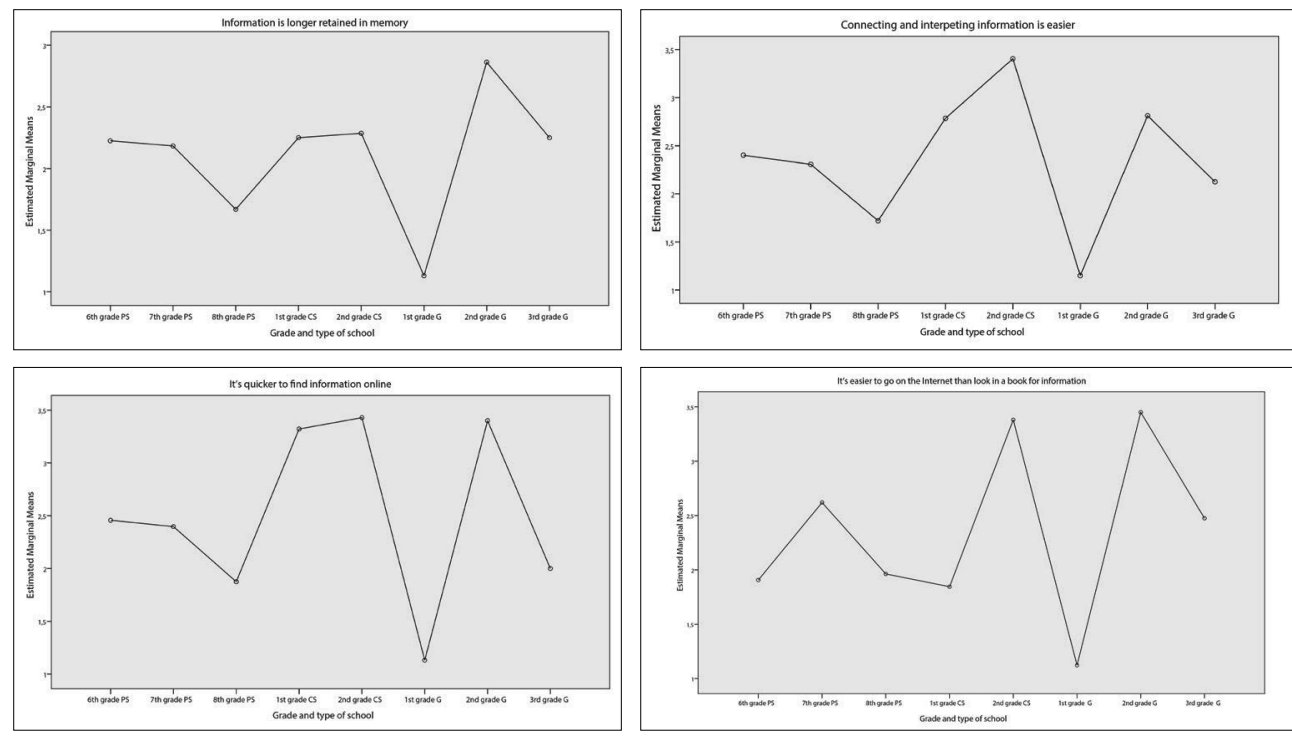

Figure 3-6. The effect of grade and type of school on perception of cognitive benefits of ITG (PS - primary school, CS - career school, G - gymnasium)

A grade and a type of school had a significant effect on almost all perceived cognitive benefits of ITG except on the process of learning. It's interesting to note that there is a certain trend among pupils in gymnasiums, where second graders 
have significantly higher assessments of memory, mental schemas, computation and reasoning than first and third graders. Estimations of career schools differ depending on types of cognitive functions. Finally, primary schools have similar trends for almost all dependent variables except for the claim that it is easier to go online than to look for information in a book (see Figure 3-6).
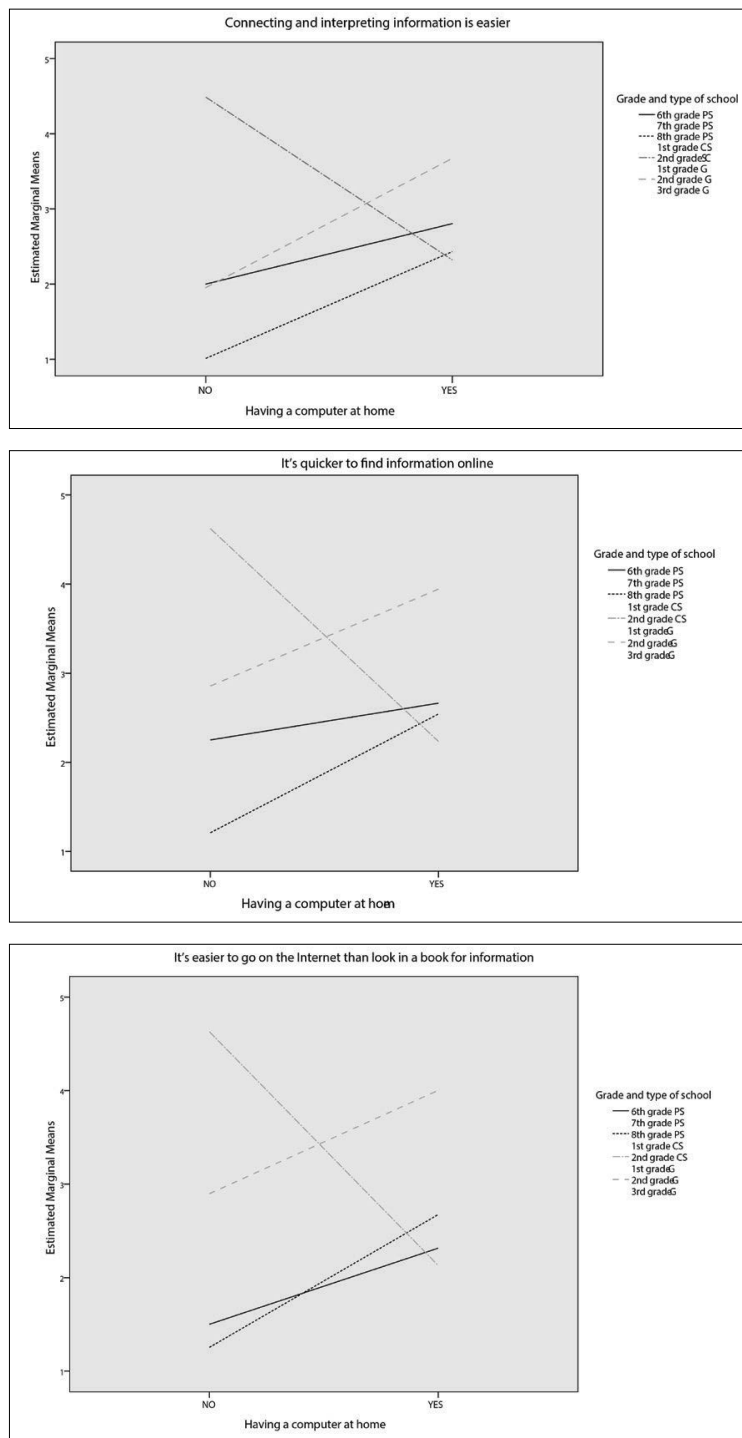

Figure 7-9. The effect of interaction of having computer at home and grade and type of school on perception of cognitive benefits of ITG (PS - primary school, CS - career school, G - gymnasium) 
Even though there was no direct effect of computer possession on the perception of cognitive benefits of ITG, there was an effect of its interaction with type of school. A subsample consisted of primary schools pupils of $6^{\text {th }}$ and $8^{\text {th }}$ grade, career school pupils of $2^{\text {nd }}$ grade and gymnasium pupils of $2^{\text {nd }}$ grade was analyzed, since all the remaining groups had computers at home. The advantages of ITG were generally considered to be smaller by those who did not own a computer at home. On the contrary, career school pupils who did not own computers estimated cognitive benefits of ITG much higher than all the other analyzed participants (see Figure 7-9).

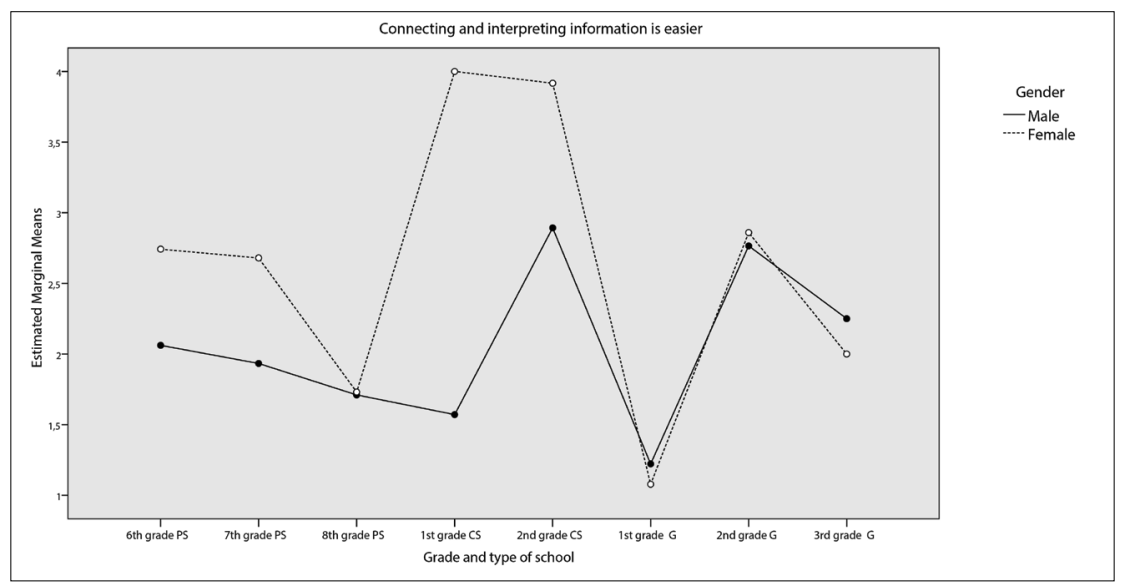

Figure 10. The effect of interaction of gender and grade and type of school on perception of cognitive benefits of ITG (PS - primary school, CS - career school, G - gymnasium)

There was also a significant effect of interaction of gender with grade and type of school on the perception of cognitive benefits of ITG. Female pupils from primary and career schools believe that connecting and interpreting information is easier with ITG in comparison to male pupils from the same type of schools. However, pupils from gymnasiums do not differ significantly in this respect, depending on gender (see Figure 10).

\section{Discussion}

The goal of this study was to examine pupils' perception of cognitive advantages of Internet usage in teaching geography (ITG) in primary and secondary schools. When researching cognitive advantages, we explored several aspects of cognition: memory, learning, mental schemas, computation and reasoning. A wide range of factors influences individuals' usage of computers (and 
the Internet), including educational background and other socio-demographic characteristics (Czaja et al., 2006). That is why we also considered the effects of pupils' gender, grade and type of school and computer possession.

In comparison to the previous study (Dragin et al., 2010), geography has become more popular in the last few years. At the same time, the Internet has become more present at schools and in teaching geography in Serbia. These two phenomena are most likely related, since Internet usage has made teaching more interesting and adequate for the N-generation.

Analyses show that pupils think that the greatest benefit of Internet usage in teaching geography is for learning $(\mathrm{M}=4.04)$. Pupils considered other cognitive benefits of ITG to be below average $(\mathrm{M}<3)$, and the effects of ITG on memory were estimated as the weakest $(\mathrm{M}=2.42)$. That was a surprising finding since majority of the relevant literature emphasizes cognitive benefits of the Internet (e.g. Durkin et al., 2009; Subrahmanyam et al., 2001a; Valentine, Marsh, Pattie and BMRB, 2005). A possible explanation might be that the Internet is more present at schools but teachers are still not using it adequately as a teaching tool and they are not accordingly instructing pupils in Internet usage. Pupils need a guide who would help them to choose information and put it into proper use. The amount of data is often overwhelming, and therefore it can hinder pupils' memory, reasoning, connecting and interpreting of information.

Although the average estimates of cognitive advantages of ITG were low, we continued with the analyses of the effects of gender, grade and type of school and computer possession on the perception of those advantages. These analyses were conducted because we wanted to determine whether these perceived smaller cognitive benefits could be explained through different perceptions of different groups of pupils. Almost all selected variables (except computer possession) influence the perception of benefits of ITG for forming mental schemas. It seems that connecting and interpreting of the information is a cognitive capability which varies significantly depending on pupils' individual characteristics.

Individual effects of selected variables have provided better insight into understanding the phenomenon of cognitive benefits of ITG. There were significant gender differences for two indicators: the connecting and interpreting of information is easier (mental schemas) and it is quicker to find information online (computation and reasoning). Female pupils generally perceive more benefits of ITG for cognitive processing. The Internet seems to help them in creating better mental representations of the data and it helps in processing new information. Previous studies indicate that there are gender differences in learning styles (Honigsfeld, 2001; Yong and McIntyre, 1992). Female learning preferences are: responsibility, structure, learning in several ways, learning alone and no mobility. This is in accordance with our findings, since Internet usage is more of an individual learning activity with low or no mobility, which is more suitable 
for female pupils. Female pupils are also better at structuring and learning in different ways and they are more responsible, which helps in organizing and understanding the mass of information that the Internet provides.

Computer possession was not a significant predictor of perceived cognitive benefits of ITG. However, computer possession interacts with grade and type of school. Sixty-three pupils (4\%) of the total sample did not have computers at home. Even though it is a rather small number compared to those who had computers, almost everyone has a computer at home nowadays, so we believe that this percentage accurately represents the general population. The comparison of these two groups (those with or without computers at home) gives us a unique insight into how the usage of computers and the Internet changes the society. Seventh grade pupils from primary schools, $1^{\text {st }}$ grade pupils from career schools and $1^{\text {st }}$ and $3^{\text {rd }}$ grade pupils from gymnasiums all have computers at home, so they were excluded from our further analyses. The rest of the sample shows a significant effect of an interaction of computer possession with grade and type of school. Primary school pupils and gymnasium pupils who own a computer at home recognize significantly the benefits of the Internet for two aspects of cognition: mental schemas and computation and reasoning. However, these differences are rather small, especially for younger pupils ( $6^{\text {th }}$ grade). On the other hand, if second graders of career schools have computers at home, they estimate the benefits of ITG to be significantly smaller than they are in the estimate of those pupils who don't own computers at home. There are two possible explanations for these findings. The first could be that pupils from career schools without a computer at home generally come from families with lower incomes and are therefore more fascinated with computer technology since it is something they probably cannot afford. The second explanation could be that parents' education of this group of pupils is low, so they might be computer-illiterate. Therefore, their children might be attracted to the Internet because it is something they don't know and understand and perhaps they idealize it. There are numerous studies that support these explanations. Family background influences school choice and career orientation of children - parents of career school pupils are less educated and have lower incomes (Bogunović and Polovina, 2007, Feldt, Kokko, Kinnuenen and Pullkinen, 2005; Gutman, Sameroff and Cole, 2003; Polovina, 2009; Show, Gilliom and Nagin, 2003; Zaslow et al., 2006).

It has been shown that grade and type of school have significant influence on the perception of benefits of ITG for three aspects of cognition: memory, mental schemas and computation and reasoning. In most of the grades and types of schools, trends are quite similar for all four indicators. In the case of primary schools, younger pupils ( $6^{\text {th }}$ and $7^{\text {th }}$ graders) perceive more cognitive benefits of ITG than the older ones ( $8^{\text {th }}$ graders), except for the search for information online where $7^{\text {th }}$ graders have the highest estimate when compared to other groups. 
These findings might be due to the content of curricula in different grades and also due to cognitive development of different age groups of pupils. In the $6^{\text {th }}$ grade pupils learn about physical geography and European regional geography and are the youngest participants with concrete way of thinking (Piaget, 2007). In the $7^{\text {th }}$ grade pupils learn about regional geography of the world (excluding Europe) and in the $8^{\text {th }}$ grade national geography is taught. In these last two grades children slowly develop abstract thinking and transition into formal operational stage (Piaget, 2007). The oldest primary school pupils ( $8^{\text {th }}$ graders) should be capable of abstract thinking and of utilizing metacognition so the Internet might not be that necessary for them as it is for younger pupils who need to physically see what they learn, which the Internet provides through the multimedia content. Furthermore, eight-graders study the topic they are very familiar with (the country they live in), so it might be that they don't really need the Internet to find additional information unlike seventh-graders who learn about less familiar subjects and the Internet can help them to broaden the knowledge of them. Finally, sixth-graders are not so independent and probably expect to get almost all necessary information from teachers and from school books.

Two types of secondary schools (gymnasiums and career schools) show similar trends for different indicators. Pupils of first grades have lower estimates of cognitive benefits of ITG when compared to the second grade pupils, especially in gymnasiums. This can be explained by the fact that second graders in secondary schools need a more diverse approach to learning and that teachers expect them to be more independent (to write reports, to actively participate in class activities) and the Internet is therefore a helpful tool for them. Furthermore, in the $2^{\text {nd }}$ grade of secondary schools, social geography and regional geography are taught and it appears that for these topics (countries, cultures, economy, etc.), the Internet is a valued source of information. Finally, third-graders in gymnasium schools learn about Serbia's geography and it seems that the Internet might be less beneficial for this topic since information is widely available elsewhere (in books, media, family, etc.).

Our results show that there is a significant interaction of gender and grade and type of school. There is a similarity in perception of cognitive benefits of ITG for both genders. In primary schools, perception of cognitive benefits of ITG gradually decreases with age. Female pupils of the $6^{\text {th }}$ and $7^{\text {th }}$ grade perceive cognitive benefits of ITG to be greater than male pupils do. In gymnasiums evaluations are almost the same for both genders. The most significant difference is found among career school pupils, where gender differences were pronounced especially among first-graders. Female pupils from career schools have assessed much greater cognitive benefits of ITG than any of the pupils from the entire sample. Findings for primary schools might be due to the fact that females generally mature faster than males in certain cognitive areas during childhood and adolescence (Lim, Han, Uhlhaas and Kaiser, 2015; Polovina, 2009). Therefore, 
they are sooner able to use metacognitive strategies and are more aware of the Internet usefulness in learning. However, the differences in secondary schools are only present in the case of career schools, while gymnasium pupils have the same results for both genders. If we look at the previous findings on the effect of interaction of computer possession with grade and type of school, career school pupils without computers estimate greater benefits of ITG. Since female pupils from career schools don't possess computers 3.5 times more frequently than males, we believe that they create these differences. They might be more fascinated with the Internet due to the low income and educational attainment of the family they come from (as mentioned before). However, the percentage of pupils who do not own a computer at home is very low, so other factors might also be responsible for these differences. Since career schools provide a job-specific training, we assume that their pupils need to think about their future sooner than those from gymnasiums who need to continue their education at universities. Female pupils are more cognitively and emotionally mature (Lim et al. 2015) and are therefore more aware of the benefits that Internet usage can bring to their education. Furthermore, for them the purpose of Internet usage is reportedly different than for males (Jackson et al., 2007; Jupiter Communications, 2000; Subrahmanyam et al., 2001a); they use the Internet predominantly for communication, which could be more useful for the process of learning than playing online video games that male pupils tend to do.

Generally speaking, this study suggests that the Internet is still not sufficiently recognized as a useful tool for teaching and learning geography in Serbia. It is an underestimated learning tool even though numerous studies have shown that the Internet is highly beneficial for demonstration, visualization and connection of data (Ally, 2004; Durkin et al., 2009; Subrahmanyam et al., 2001a; Valentine et al., 2005). Therefore, with respect to teaching methods, primary and secondary school education in Serbia is falling behind primary and secondary school education in more developed countries (such as USA, UK, Australia, etc.). As Clark has pointed out (2003), effective learning and teaching is nowadays a combination of the Internet (computer)-based learning and traditional methods (direct teaching, demonstrative teaching, etc.). Technologically supported learning must be encouraged by the state and strategies should be developed and implemented by schools, teachers and parents. The society can be changed for the better through the education of teachers, above all else, since teachers have always been primary knowledge bearers (Lieberman and Mace, 2009; Lieberman and Miller, 2001). Finally, the question is: are geography teachers in Serbia aware of cognitive and general benefits of the Internet usage in teaching and what are the factors that affect the Internet usage at schools? Therefore, future research should put teachers into focus, specifically their attitudes towards ICT-based education and educational methods. 
As every study, this one also has certain shortcomings. Internet technologies are rapidly evolving and when this study was initially conceptualized, the Internet was predominantly accessed by computers. In the last two years, smart technologies (smart phone, tablets, television, etc.) have become available in Serbia for almost all, regardless of socio-economic status. Future studies should include all different media that provide Internet access. Nowadays, the question is not whether there is Internet access during classes, but whether teachers encourage Internet usage while learning and through which media predominantly. This topic is always in transition and the need for research is ever present. The results are continuously being outdated, but the trend remains - new technologies shape the processes of learning and teaching and advance education.

\section{Conclusion}

The purpose of this research was to determine pupils' perception of the benefits of the Internet use on cognitive processing of geography subject. Additionally, we examined the influence of gender, grade and type of school and computer possession at home on these perceptions. Most of the cognitive benefits have been assessed as low except for learning. There were two significant main effects - gender and grade and type of school. Beside that, there were two significant interaction effects - computer possession with grade and type of school and gender with grade and type of school. Results indicate that following groups perceive higher benefits of the Internet use while teaching geography for cognitive processing: female pupils, younger primary school pupils $\left(6^{\text {th }}\right.$ and $7^{\text {th }}$ grade), $2^{\text {nd }}$ grade pupils of secondary schools (especially for gymnasiums), career school pupils without computer and younger female pupils of primary and career school.

This research was conducted in the developing country (Republic of Serbia) and results indicate that Internet is still not used appropriately as a teaching tool. Therefore, there is a growing need for an adequate strategy of implementing Internet technologies in school education. We believe that teachers as exemplars have the most important role in carrying out these strategies and therefore are responsible for improving cognitive processing of pupils. This research advances education system and our understanding of adolescents' attitudes and skills and provides us with a broader perspective on the changes that technologies are bringing in schools. 


\section{Acknowledgement}

This research was supported by the Project 142-451-2511/2017-04 of the Provincial Secretariat for Science and Technological Development, ECAP Vojvodina Province (Serbia).

\section{References}

Ally, M. (2004). Foundations of Educational Theory for Online Learning. In T. Anderson, \& F. Elloumi (Eds.), Theory and Practice of Online Learning (pp. 3-30).

Andjelković, S., \& Pavlović, D. (2015). New media in teaching of geography: literature review. Bulletin of the Serbian Geographical Society, 95(4), 173-194.

Bevort, E., \& Breda, I. (2008). Adolescents and the Internet: Media appropriation and perspectives on education. In P. C. Rivoltella (Ed.), Digital literacy: Tools and methodologies for information society (pp. 140-165). Hershey, PA: Idea Group Inc.

Bogunović, B., \& Polovina, N. (2007). Obrazovno-materijalni kontekst porodice i odnos učenika prema školovanju. Zbornik Instituta za pedagoška istraživanja, 39(1), 99-114.

Carlsson, U., \& Facht, U. (Eds.) (2002), Medie-sverige 2001/2002, statistik och analys [Media-Sweden 2001/2002, Statistics and analyses]. Gothenburg: NORDICOMSverige.

Clark, D. (2003). Blended Learning. Retrieved from https://www.scribd.com/ document/84278560/Clark-D-Blended-Learning.

Czaja, S. J., Charness, N., Fisk, A. D., Hertzog, C., Sankaran, Nair, N., Rogers, W. A., \& Sharit, J. (2006). Factors Predicting the Use of Technology; Findings from the Center for Research and Education on Aging and Technology Enhancement (CREATE). Psychology and Aging, 21(2), 333-352.

DeBell, M., \& Chapman, C. (2006). Computer and Internet Use by Students in 2003. Washington, DC: National Center for Educational Statistics, US Department of Education. Retrieved from https://nces.ed.gov/pubs2006/2006065.pdf.

Dragin, A., Solarević, M., \& Ivkov-Džigurski, A. (2010). The use of the Internet in the learning process. $2^{\text {nd }}$ Serbian geographers' congress, University of Novi Sad, Faculty of Sciences, Department of Geography, Tourism and Hotel Management, Novi Sad.

Durkin, K., Conti-Ramsden, G., Walker, A., \& Simkin, Z. (2009). Educational and interpersonal uses of home computers by adolescents with and without specific language impairment. British Journal of Developmental Psychology, 27, 197-217.

Feldt, T., Kokko, K., Kinnunen, U., \& Pulkkinen, L. (2005). The role of family background, school success and career orientation in the development of sense of coherence. European Psychologist, 10(4), 298-308. 
Greenfield, P., \& Yan, Z. (2006). Children, Adolescents, and the Internet: A New Field of Inquiry in Developmental Psychology. Developmental Psychology, 42(3), 391-394.

Gross, E. F. (2004). Adolescent Internet use: What we expect, what teens report. Applied Developmental Psychology, 25, 633-649.

Gutman, M., Sameroff, A., \& Cole, R. (2003). Academic growth curve trajectories from 1st to 12th grade: effects of multiple social risk factors and preschool child factors. Developmental Psychology, 39(4), 777-790.

Honigsfeld, A. M. (2001). A comparative analysis of the learning styles of adolescents from diverse nations by age, gender, academic achievement level, and nationality. Doctoral dissertation, St. John's University.

Jackson, L. A., Samona, R., Moomaw, J., Ramsay, L., Murray, C., Smith, A., \& Murray, L. (2007). What children do on the Internet: Domains visited and their relationship to socio-demographic characteristics and academic performance? CyberPsychology and Behavior, 10, 182-190.

Johnson, G. M. (2006). Internet use and cognitive development: A theoretical framework. E-Learning, 4, 565-573.

Johnson, G. M. (2008a). Cognitive processing differences between frequent and infrequent Internet users. Computers in Human Behavior, 24, 2094-2106.

Johnson, G. M. (2008b). Verbal and visual reasoning in relation to patterns of Internet use. Internet Research, 18(4), 382-392.

Johnson, G. M. (2010a). Internet Use and Child Development: Validation of the Ecological Techno-Subsystem. Educational Technology \& Society, 13(1), 176-185.

Johnson, G. M. (2010b). Internet Use and Child Development: The TechnoMicrosystem. Australian Journal of Educational \& Developmental Psychology, 10, 3243.

Johnson, G. M. (2010c). Young children's Internet use at home and school: Patterns and profiles. Journal of Early Childhood Research, 8, 282-293.

Joinson, A. N. (2003). Understanding the psychology of Internet behavior: Virtual worlds, real lives, New York: Palgrave MacMillan.

Jupiter Communications (2000). Targeting Teens is a Gender Game.

Lemke, K. A., \& Ritter, M. E. (2000). Virtual Geographies and the Use of the Internet for Learning and Teaching Geography in Higher Education. Journal of Geography in Higher Education, 24(1), 87-91.

Lenhart, A., Madden, M., \& Hitlin P. (2005). Pew Internet and American Life Project: Teens and Technology; Youth are leading the transition to a fully wired and mobile nation. Retrieved from http://www.pewinternet.org/files/old-media/Files/ Reports/2005/PIP_Teens_Tech_July2005web.pdf.pdf.

Lieberman, A., \& Mace, D. P. (2009). Making Practice Public: Teacher Learning in the $21^{\text {st }}$ Century. Journal of Teacher Education, 61(1-2), 77-88. 
Lieberman, A., \& Miller, L. (Eds.). (2001), Teachers caught in the action: Professional development that matters. New York: Teachers College Press.

Lim, S., Han, C. E., Uhlhaas, P. J., \& Kaiser, M. (2015). Preferential Detachment During Human Brain Development: Age and Sex-Specific Structural Connectivity in Diffusion Tensor Imaging (DTI) Data. Cerebral Cortex, 25(6), 1477-1489.

Leščešen, I., Dolinaj, D., \& Pantelić, M. (2017). Survey of results achieved on geography questions on final exam for elementary school students - sample analysis. Researches Reviews of the Department of Geography, Tourism and Hotel Management, 46(2), 65-75.

Macia Arce, X. C., Rodriguez Lestegas, F., \& Armas Quinta, F. X. (2017). Notes for a didactic model of critical geography. Analysis and evaluation of a classroom experience with university students from Galicia (Spain). Geographica Pannonica, 21(3), 191-197.

Milošević, D., Ivanović Bibić, Lj., Đukičin, S., Ivkov-Džigurski A., \& Ristanović, B. (2016). The possibilities of application of programmed instruction in the sixth grade of the second cycle of education in accordiance with standards. Geographica Panonnica, 20(2) 96-104.

Piaget, J. (2007). The Construction Of Reality In The Child. Oxon: Routledge.

Polovina, N. (2009). Obrazovanje roditelja i odnos prema školi njihovih ćerki i sinova. Zbornik Instituta za pedagoška istraživanja, 41(1), 76-99.

Ritter, M. E., \& Lemke, K. A. (2000). Addressing the "Seven Principles for Good Practice in Undergraduate Education" with Internet-enhanced Education. Journal of Geography in Higher Education, 24(1), 100-108.

Roberts, D. F., \& Foehr, U. G. (2008). Trends in media use. The Future of Children, 18, 11-37.

Show, S., Gilliom, M., \& Nagin, D. (2003). Trajectories leading to school-age conduct problems. Developemental Psychology, 39(2), 189-200.

Singh, H., \& Reed, C. (2001). A White Paper: Achieving Success with Blended Learning. Centra Software. Retrieved from https://maken.wikiwijs.nl/ userfiles/f7d0e4f0bd466199841ede3eea221261.pdf

Stojanović, T., Penjišević, I., Lukić, T., Živković, J. (2017). Computer literacy of young people in Serbia and regional differences. Geographica Panonnica, 21(1) 43-53.

Subrahmanyam, K., Greenfield, P. M., Kraut, R. E., \& Gross, E. (2001a). The impact of computer use on children's development. Journal of Applied Developmental Psychology, 22, 7-30.

Subrahmanyam, K., Kraut, R., Greenfield, P., \& Gross, E. (2001b). New forms of electronic media: The impact of interactive games and Internet on cognition, socialization, and behavior. In D. G. Singer, \& J. L. Singer (Eds.), Handbook of children and the media (pp. 73-99). Thousand Oaks, CA: Sage. 
Tarpley, T. (2001). Children, the Internet, and other new technologies. In D. G. Singer, \& J. L. Singer (Eds.), Handbook of children and the media (pp. 547-556). Thousand Oaks, CA: Sage.

Valentine G., Marsh J., Pattie C., \& BMRB. (2005). Children and young people's home use of ICT for educational purposes: The impact of attainment at key Stages 1-4. Research Report No. 672, University of Leeds.

Višnić, T., Ivanović Bibić, Lj., Đukičin Vučković, S., Ivkov-Džigurski, A., \& Konečnik Kotnik, E. (2017). The Evaluation of the Role Of Teaching Aids in Stimulating Pupils' Activation in Geography. Journal of the Geographical Institute "Jovan Cvijić" SASA, 67(2), 179-194.

Yong, F. L., \& McIntyre, J. D. (1992). A comparative study of the learning style preferences of students with learning disabilities and students who are gifted. Journal of Learning Disabilities, 25(2), 124-132.

Zaslow, M., Weinfield, N., Gallagher, M., Hair, E., Ogawa, J., Egeland, B., Tabors, P., \& Temple, J. (2006). Longitudinal prediction of child outcomes from differing measures of parenting in low-income sample. Developmental Psychology, 42(1), 2737.

Živković, Lj., \& Jovanović, S. (2006). Realizacija oblika i metoda rada upotrebom kompjutera u nastavi geografije. Zbornik radova - Geografski fakultet Univerziteta u Beogradu, 54, 249-260.

Živković, Lj., Jovanović, S., Đorđević, I., \& Golubović, N. (2017). An interdisciplinary approach to teaching contents geography in primary school. Bulletin of the Serbian Geographical Society, 97(1), 137-158. 